\title{
In Vivo Studies on the Mode of Action of $\mathrm{LH}$
}

\author{
N. OHSAWA \\ Central Institute for Experimental Animals, Kawasaki and the Third Department of \\ Internal Medicine, Faculty of Medicine, University of Tokyo, Tokyo, Japan
}

The mode of action of LH on testosterone biosynthesis in male rats and mice has been studied in vivo. In rat's experiments, testicular vein blood was collected and testosterone in the plasma was measured by fluorometry of Ohsawa et al (1969). After intravenous administration of $\mathrm{LH}$ testosterone output started to increase within three minutes and reached the maximum level in ten minutes. Thus, the effect of LH on testosterone secretion from rat's testis has been revealed to be quite rapid, like the effect of ACTH on adrenal cortex. The similar results have been obtained in mice. After intratesticular injection of $\mathrm{LH}$, the content of testosterone in mouse testis started to increase within three minutes and reached the plateau in ten minutes.

Cyclic-3', 5' AMP, proposed mediator of action of $\mathrm{LH}$ in the Leidig cell, has been tested in the same assay system as described above, concerning the capacity of stimulation of testosterone synthesis in the male animals. Administration of cyclic AMP caused a prompt and significant increase in testosterone production in testes of both specieses. Cyclic AMP apparently mimics the action of $\mathrm{LH}$.

Inhibitors of protein and nucleic acid synthesis have also been tested in the same system. Cytosine-arabinoside, an inhibitor of DNA synthesis, and actinomycin D, an inhibitor of m-RNA synthesis, have been shown to have no influence on the action of LH on testosterone synthesis. On the contrary, cycloheximide, a known inhibitor of protein synthesis, completely blocks the steroidgenic activity of $\mathrm{LH}$ as well as cyclic AMP. From these results, it is postulated that LH exerts its action on the testosterone biosynthesis through the formation of cyclic AMP, followed by rapid synthesis of unknown regulator protein.

(See pp. 645 653) 


\title{
シンポジゥム I ホルモンの作用機序
}

\section{LH の作用機序に関する研究}

\author{
——in vivo における c-AMP 説の検討——
}

\section{実験動物中央研究所, 東大第三内科}

大沢仲昭

\section{I 緒 言}

LH の作用機序の研究において in vitro の成績は多くみられるが， in vivo の検討は少なく，殊に睪丸 の testosterone 合成におよぼす作用に関しては Eik-Nés らのイヌを用いる成績以外みるべきものがない現 状である．その主要な原因の一つは，小動物（ラット，マウス）を用いて LH の作用を手軽倹定しうる 系がないためと考えられる. 今回の報告においては, 雄ラットおよびマウスを用いる新しい LH の作用の 検定方法の開発と，てれを用いての LH の作用機序の研究，特にその作用伝達物質と想定される c-AMP

Table 1. Bioassay of LH

\begin{tabular}{l|l|l}
\hline \hline 1. Rat Ventral Prostate Weight & Greep & 1942 \\
2. Rat Ovarian Hyperemia & Farris & 1946 \\
3. Weaver Finch & Witschi & 1955 \\
4. Rat Ovarian Ascorbic Acid Depletion & Parlow & 1958 \\
5. Rat Super Ovulation & Zarrow & 1958 \\
6. Rat Ovarian Cholesterol Depletion & Bell & 1964 \\
7. Rat Testicular Vein Plasma Testosterone & Ohsawa & 1969 \\
8. Mouse Testicular Testosterone & Ohsawa & 1969 \\
\hline
\end{tabular}

を中心として検討した成績を述べる。

\section{III ラットおよびマウスの睪丸の testosterone 合成並びに分 泌を指標とする LH の作用 の検定方法}

従来の LH の生物検定法は LH の作用の間接効果 (例兊ば Rat Ventral Prostate Weight Method) あるいは意義の不明な作用 (Rat Ovarian Ascorbic Acid Depletion Method) を指標としたものが多い (Table 1). LH の萃丸に対する直接的, 本質的作 用は Leidig 細胞を刺激し, cholesterol から等丸 性 androgen（主として testosterone）の合成を促 進する処にある (Fig. 1). 我々はての点に注目しラ ットおよびマゥスの箤丸における testosterone の
Fig. 1. Effect of LH on Testosterone Biosynthesis.

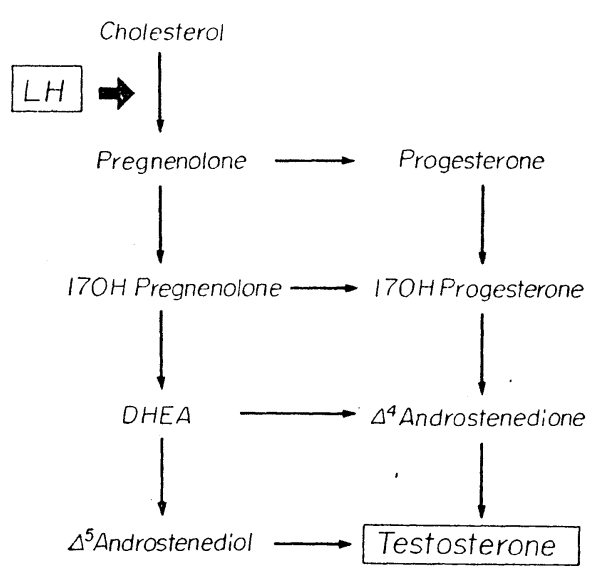


合成分必を指標とする新しい LH の生物検定法を開発した.

a) ラットの睪丸静脈血中 testosterone を指標とする LH 検定法 (rat testicular vein blood testosterone method) $)^{2)}$

ての方法は ACTH における Lipscomb-Nelson 法 (rat adrenal vein blood corticosterone method) に相当するものである. ラットは SD 系の雄, 生後 $13 \mathrm{~W}$ 以上のものを用いた．乙の方法の開発のためには 娈丸静脈血の採取法と testosterone 測定法が確立される必要がある. Fig. 2 は我々のラット㖕丸静脈血採

Fig. 2. Method for Collection of Testicular Vein Blood of Rats.

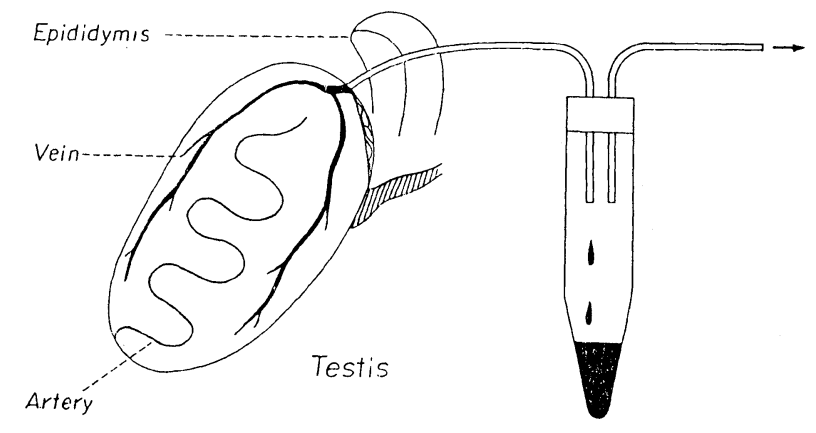

取法を示したものである. 全身にへパリン投与後穜丸の上極の部分で左右の静脈の合する点に小切開をほど てし，あふれ出る血液を吸引する．乙の方法では從来数十分を要していた採血に比し 3 分間に $0.5 \mathrm{ml}$ 以上の 學丸静脈血の採取が容易であり，従つて経時的変化を追及するのに適している.

Table 2 は rat testicular vein blood testosterone method の flow chart である. LH を静注投与一 定時間（10分）後 3 分間害丸静脈血液を採取，plasma を分離する. plasma 中の testosterone は Table 3 に示す如き，我々が開発した testosterone の赤色硫酸螢光を応用する方法で測定する.（詳細はすでに発表 した $\left.{ }^{3}\right)$. 全操作は一日で行なうことが出来る.

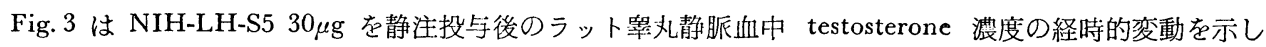
たものである，一群は 5 匹平均で，平均值と SE を示す．以下の表も同様である．LH 亿対するラット睪 丸の反応は極めて速かで投与 3 分後にはすでに testosterone の分泌増加が認められ, 10分後には plateau に 達する．Fig. 4 は比䡥のために ACTH に対する副腎の反応を示したものである．下垂体摘出ラットに ACTH $10 \mathrm{mU}$ を静注すると数分後に副腎静脈血中の corticosterone の分泌が増加し 5 〜 10分後に plateau

Table 2. Bioassay of $\mathrm{LH}$

\begin{tabular}{l|c}
\hline \multicolumn{1}{c}{ (rat testicular vein blood testosterone method) } \\
\hline \multicolumn{1}{c|}{ Treatment } & Timing (Min.) \\
\hline \hline 1. Pentobarbital ip. & -15 \\
2. LH or test solution, iv. & 0 \\
3. Laparotomy & 8 \\
4. Heparin iv. & 9 \\
5. Start of collection of testicular vein blood & 10 \\
6. End of collection of testicular vein blood & 13 \\
7. Plasma subjected to fluorometry & \\
\hline
\end{tabular}


Table 3. Fluorometry of Testosterone in Rat Testicular Vein Plasma

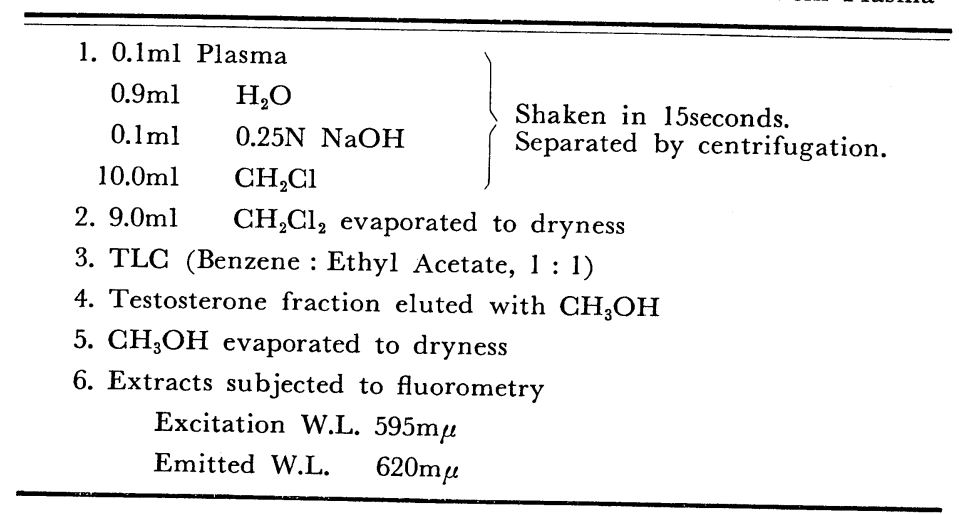

Fig. 3. Changes in testosterone levels in testicular vein blood of rats after intravenous injection of $\mathrm{LH}$.

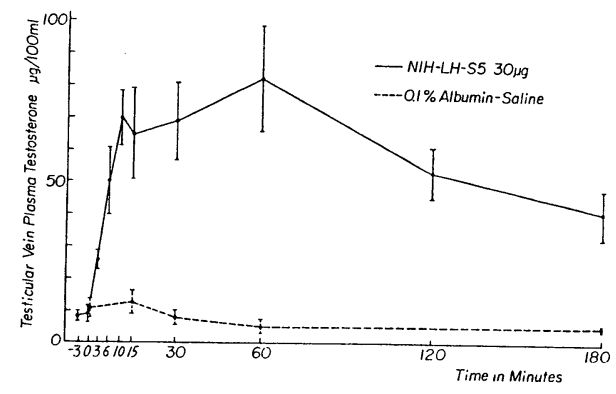

に達するととはよく知られている4．LH の作用が ての様に ACTH と全く同椂極めて速かであるてと は，LH の作用機序を検討する際にこの迅速性を説 明しうる仮説を立てる必要があることを意味してい る. 又 $\mathrm{LH}$ と ACTH の作用の pattern が極めて 類似しているととは両者の作用機序が同様の機構を 有するととを示唆し, 従つて ACTH の作用機序の 研究が LH の研究に極めて参考になると考えられ る.

Fig. 5 はこの rat testicular blood testosterone method L LH の bioassay に用いた場合のdoseresponse curve を示したものである. LH $0.25 \mu \mathrm{g}$ $\sim 2 \mu \mathrm{g}$ の間で standard curve を得る. Fig. 6 は LH 投与時の辠丸の流血量の増加を示したものである. 卵巣の流血量が LH により増加することは良く知

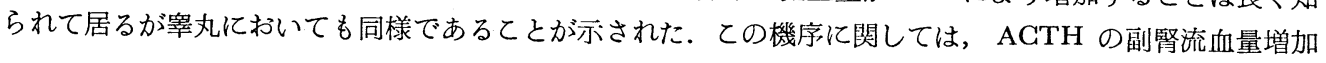

Fig. 4. Changes in corticosterone output in adrenal vein blood of rat after intravenous injection of ACTH.

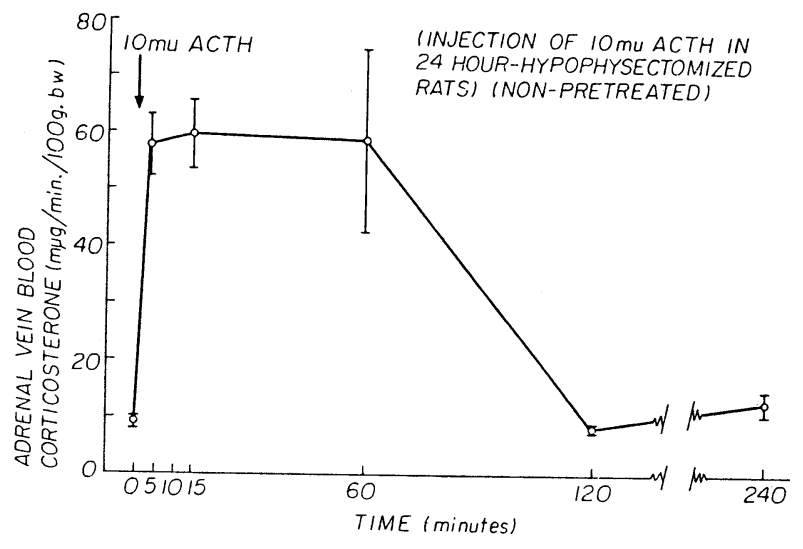

第46巻 第 6 号 
Fig. 5. Dose-response relationship between $\mathrm{LH}$ and testosterone output in rat testicular vein blood.

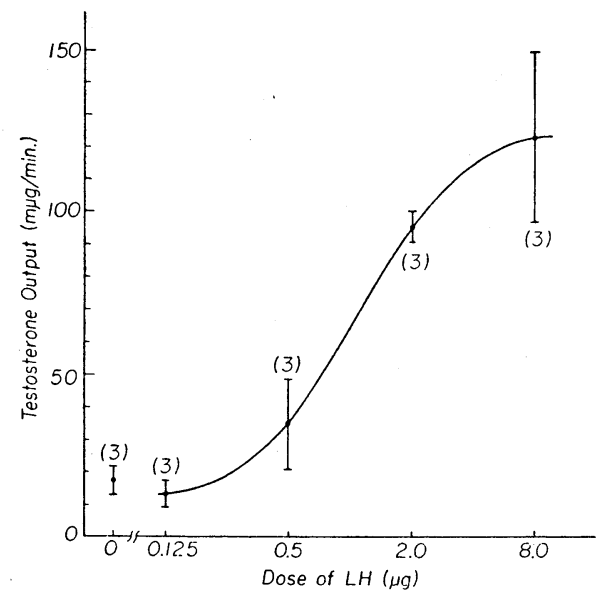

Fig. 6. Effect of LH on rat's testicular plasma flow.

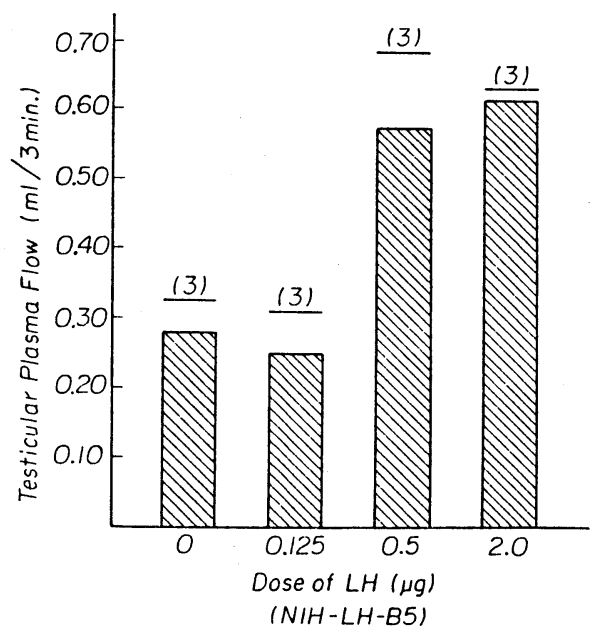

作用の機序と同様に adenosine 仮説が成立し得るか否か検討中である.

b）マウス闰丸中 testosterone を指標とする LH の検定法 (mouse testicular testosterone method) ${ }^{5}$ ) 上述のラットの方法は LH の作用の検定系として優れたものであるが，感度わよび辠丸静脈血の採取の 困難さの点で routine の検定法としては問題があり，マウスを用いる方法が開発された．即ちマウスに LH を投与後鋅丸を摘出し，その中の testosterone を測定する．乙の際 LH の投与方法として全身投与の 代りに粹丸内へ直接注入する局所投与法を採用することにより，著しく感度が上昇した．ラットおよびマウ スの殬丸の循環系は, 動脈が辠丸の中心を走り，てれから四方へ血液が拡散して周囲の被膜下へ達すると静 脈が集めて testicular vein となる. 従つて辠丸中へ LH を microsyringe で注入すると血液の自然の流 れに沿つて四方へ拡散するため，丁度動脈へ投与したと同じ効果をうるととが出来る利点がある.

Table 4 は mouse testicular testosterone method の術式を示したものである. マウスは生後13W以上 の ICR-JCL 系の雄を用いた LH を $10 \mu \mathrm{l}$ の溶液とし, microsyringe で右の䅸丸内へ注入し，10１5分 後その辠丸を摘出し，その中の testosterone を測定する. 殬丸 homogenate 中の testosterone の測定に は前述の章丸静脈血中 testosterone の測定法を改変して用いる. 即ち混入する大量の sterol を除くため抽 出後, 石油エーテル $/ 70 \%$ タノール間の分配操作を插入する. 必要に応じ, acetylation および TLC 操 作を加える。 それ以外はほぼ同様である。

Table 4. Bioassay of $\mathrm{LH}$

\begin{tabular}{lr}
\hline \multicolumn{2}{c}{ (mouse testicular testosterone method) } \\
\hline \multicolumn{1}{c}{ Treatment } & Timing (Min.) \\
\hline 1. Pentbarbital ip. & -15 \\
2. Laparotomy, Exposure of r. Testis & 3 \\
3. Injection of 10 $\mu$ l of LH or Test Solution into $r$. Testis with Microsyringe & 0 \\
1. Removal of $r$. Testis & 15 \\
5. Homogenate of r. Testis subjected to Fluorometry for Testosterone & \\
\hline
\end{tabular}


Fig. 7. Changes in testosterone content in mouse testis after intratesticular administration of $\mathrm{LH}$.

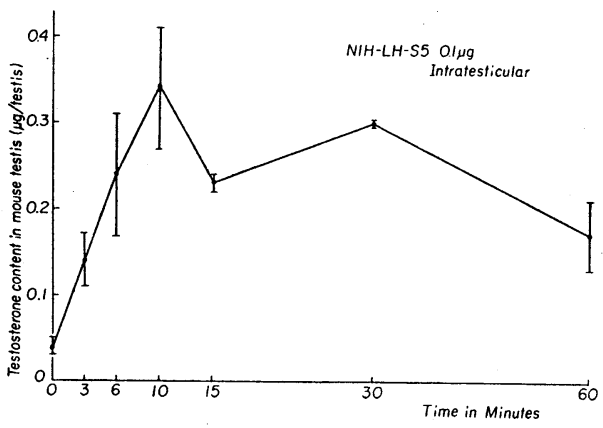

Fig. 8. Dose-response relationship between $\mathrm{LH}$ and testcsterone content in mouse testis.

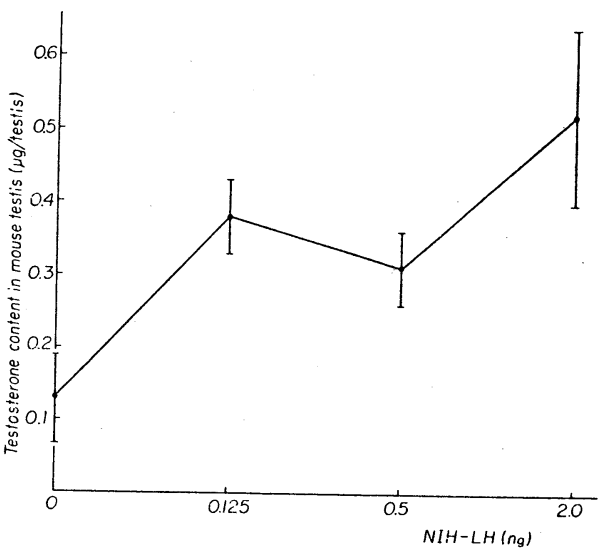

Fig. 9. Dose-response relationship between $\mathrm{LH}$ and testosterone content in mouse testis.

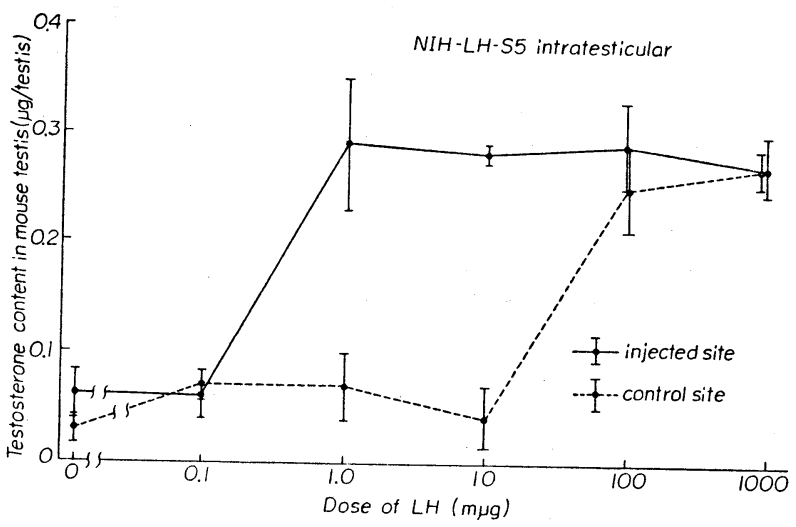

Fig. 7 は NIH-LH-S5 $0.1 \mu \mathrm{g}$ をマウス睪丸内へ投与した際の辠丸中 testosterone 量の経時的変化を図示 したものである. ラットの成績と同じく, testosterone の合成は LH 投与後 3 分で増加が証明され, 10分 で maximum に達する. 即ちマウスにおいても LH の作用は極めて速かであるてとが明らかである.

Fig. 8 はこの mouse testicular testosterone method を LH の bioassay 亿用いた際の dose response curve を示したものである. $0.1 \sim 2.0 \mathrm{~m} \mu \mathrm{g}(\mathrm{ng})$ の LH が検出しうる可能性が認められる. Fig. 9 は同様 LH の bioassay に用いた際に LH を注入した側と, その反対側（対照側）の辠丸中の testosterone 量を 比較したものである. 投与側の鋅丸は $1.0 \mathrm{~m} \mu \mathrm{g}$ の LH で十分な反応を示して居る. 反対側の辠丸は $100 \mathrm{~m} \mu \mathrm{g}$ の $\mathrm{LH}$ で反応を示すのが認められる. との反対側の睪丸の反応は，投与された LH が全身循環にとりこま れた効果と考えられる．殬丸内注入側の検出感度が100倍高いととは, 局所投与の有用性を明らかに示すもの と考えられる. との mouse tesitcular testosterone method は現在尚検討中であるが，完成した際には従来 の LH の bioassay の 100〜1000倍高感度の方法が得られるととが期待される. 又との方法を LH 以外の 物質の作用の検討に応用する際に，微量で反応を証明し得ると共に，全身循環にとりとまれた場合副作用の 出現する物質（例えば c-AMP，核酸・蛋白合成阻害洬など）においても微量で有効なため，全身に対する 
副作用の心配なく実験を行ないうる利点がある.

\section{LH の作用機序仮説-c-AMP 説}

LH が粹丸の Leidig 細胞に作用して testosterone の合成分泌を促進する機棈として，LH が細胞内へ 入らず，細胞膜の特定部位（receptor ?) と結合して作用をおよぼすと考えられている，従つて LH が Leidig 細胞内での testosterone 合成を調節するためには細胞内部においてその情報を伝達する mediator が必要である.との mediator として現在注目をあびているのが Cyclic 3',5'-AMP である ${ }^{6}$. 即ち Fig. 10 に示される如く，LH は Leidig 細胞の膜において adenyl cyclase の活性を增強する結果，ATP からの c-AMP 産生か增加し，てれが何等かの機構を介して cholesterol から pregnenolone への転換を促進する ととにより testosterone 合成を增強するとされる.

更に最近 in vitro の研究において, ACTH の作用機構と同様に c-AMP が仮想の作用蛋白 (regulator protein）の産生を促進し，てれを介して testosterone 合成を調節するといわれている. 我々はての仮説に ついて，上迶のラットおよびマウスを用いる LH の桧定法を応用して検討中であるが，今回は予備的成績 として 1) c-AMP の効果２）核酸・蛋白質合成阴害剂の効果についての成績を述べる.

\section{IV c-AMP の in vivo における testosterone 合成促進効果}

まず c-AMP が LH の testosterone 合成促進効果を mimic するか否かを梌討した。 Fig.11 はラット

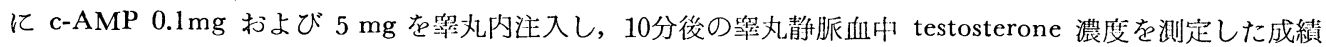
で c-AMP 5mg の投与で增加が認められる(各群は 4 乃至 5 匹よりなる. 以下同様). Fig. 12 はその際の

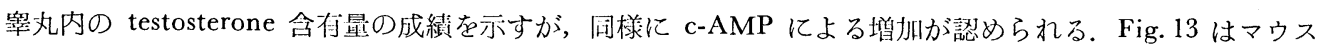

Fig. 10. Proposed mode of action of LH on testosterone biosynthesis.

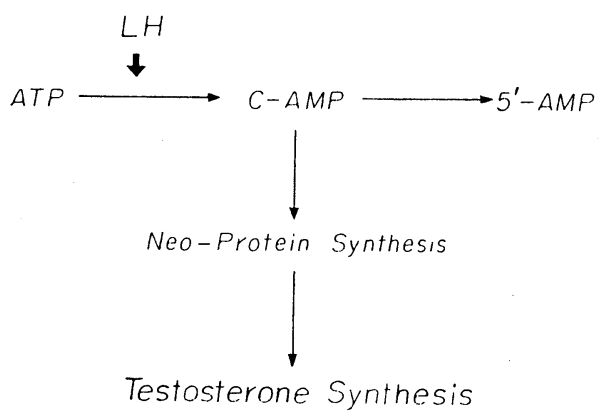

Fig. 11. Effect of c-AMP on testosterone secretion in rat.

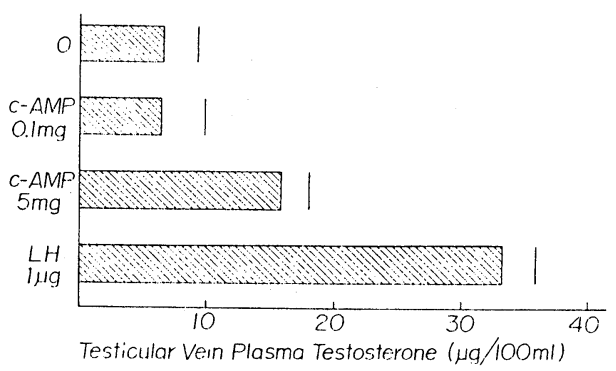

Fig. 12. Effect of c-AMP on Testosterone Synthesis in Rat's Testis.

Fig. 13. Effect of C-AMP on Testosterone Synthesis in Mouse Testis.
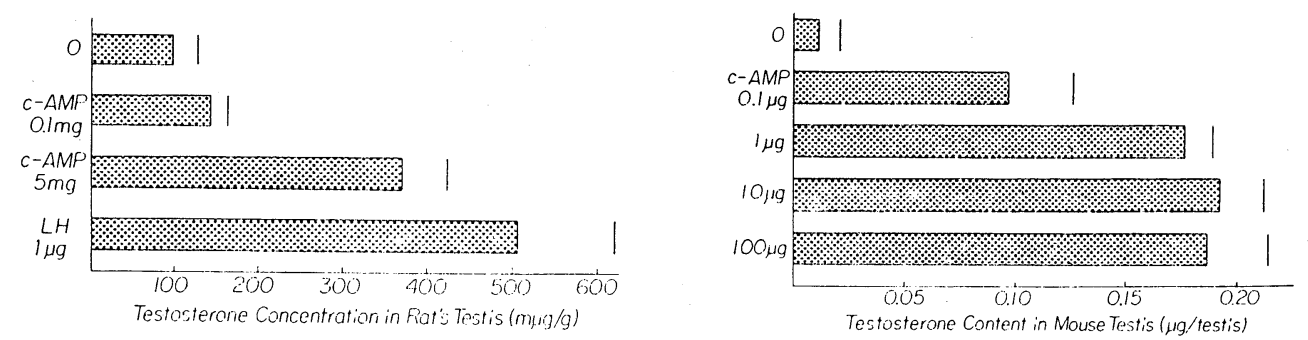
において c-AMP を婻丸内に投与した際の testosterone 含有量の変動 を示したもので, $0.1 \mu \mathrm{g} の \mathrm{c}-$ AMP で有意の testosterone 増加が認められる. この際の辠丸組織内の c-AMP 濃度はマウスの辤丸 重量が $100 \mathrm{mg}$ 程度として $10^{-6} \mathrm{M}$ 程度の final concentration と推定される. ラットとマウスの間で cAMP に対する粰丸の反応の強さに大きな差の認め られる理由は不明であり，現在検討中である.

Fig. 14 はマウスにおいて c-AMP $1 \mu \mathrm{g}$ を辤丸内 へ注入した際の穜丸内 testosterone 含有量の時閂 的変動を示したものである．LHより少しわくれる が，c-AMP 投与後速やかな testosterone 合成の促 進が認められる。

以上の成績から c-AMP は LH と同様極めて速 かにラットおよびマウスの㧝丸における testosterone の合成を促進するととが in vivo の夹駼から 想定される.
Fir. 14. Changes in testosterone content in mouse testis after intratesticular administration of c-AMP.

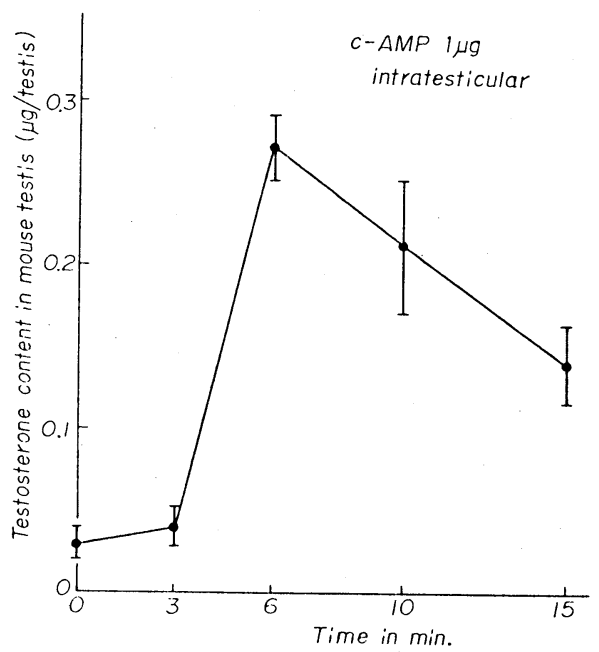

\section{V 核酸および蛋白合成阻害剂の testosterone 合成に及ぼす効果}

次に LH の等丸における testosterone 合成促進作用が, ACTH の如く, c-AMP を第1の mediator とし，次いで作用蛋白（regulator protein）の合成を介して発揮されるか否かを検討するために，核酸及び 蛋白の合成阻害剂の LH の testosterone 合成促進作用に及ぼす效果を検討した. 一般に蛋白の新しい合成 の際には DNA の合成，m-RNA の transcription の促進を介して ribosome において蛋白合成が促進さ れる. ての各 step の阻害剤として DNA 合成に対し Cytosine-Arabinoside, m-RNA の transciption に対し Actinomycin D, ribosome に扔る protein 合成に対し Cycloheximide を検討した（Table 5).

Fig. 15 は Cytosine-Arabinoside $100 \mu \mathrm{g}$ をマウスに静注投与し DNA の合成を抑制したと考えられる状 態で10分後に LH $1 \mu \mathrm{g}$ を穜丸内に投与し，殬丸中の testosterone 合成を検討した成績を示す。図にみられ

Table 5. Site of Action of Inhibitors

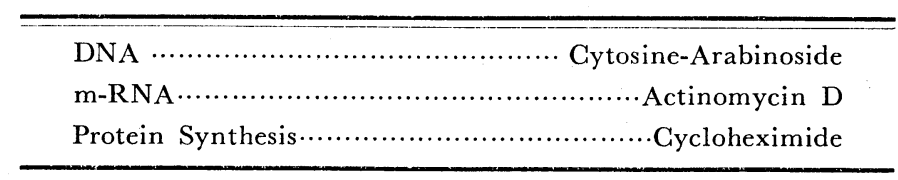

Fig. 15. Effect of Cytosine-arabinoside on Testosterone Synthesis in mouse Testis.

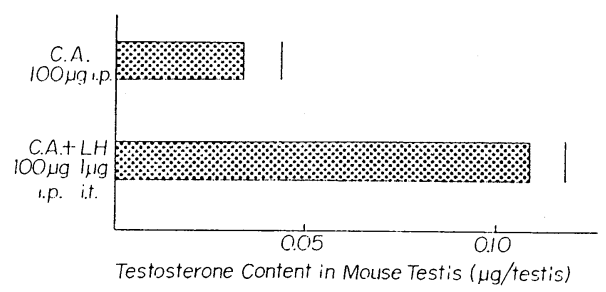

Fig. 16. Effect of Actinomycin D on Testosterone Synthesis in Mouse Testis.

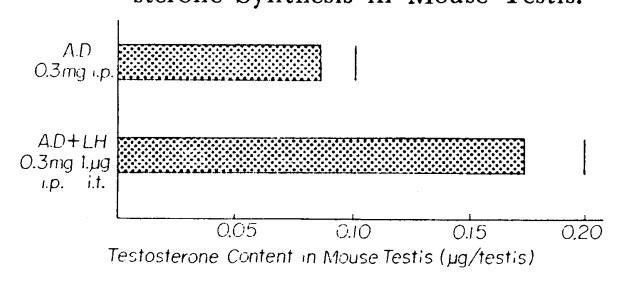


るでとく Cytosine-Arabinoside は LH の作用を阻害しないととが認められる. Fig. 16 は Actinomycin D $0.3 \mathrm{mg}$ を腹腔内に投与， 1 時間半に $\mathrm{LH} 1 \mu \mathrm{g}$ を箤丸内に投与し，箤丸中の testosterone 合成を検討し た成績を示すが，Actinomycin D により m-RNA の transcription が抑制されたと想定される状態でも LH の作用は阻害をうけない，以上の成績から LH の急性の効果の際に新しい核酸合成は必要でない可能 性が示唆される. 又核酸合成を介する蛋白の合成の際には数十分の lag time を要するが，LH の testosterone 合成促進作用は前述の如く極めて速かである点からもこの機序が関与している可能性は少ないと考え られる.

Fig. 17. Effect of Cycloheximide on Testosterone Synthesis in Mouse Testis.

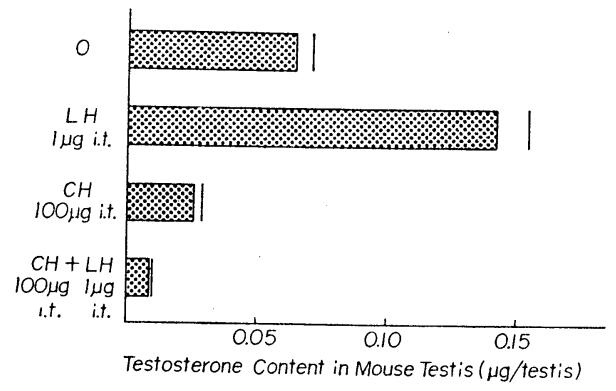

Fig. 18. Effect of Cycloheximide on c-AMP induced Testosterone Synthesis in Mouse Testis.

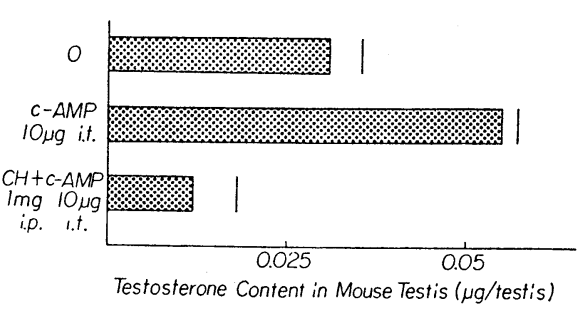

此に反し蛋白合成阻害剤である Cycloheximide $100 \mu \mathrm{g}$ を辠丸内に注入し，投与30分後に testosterone 合成能を検討した結果，Fig. 17亿みられる如く resting level の testosterone 合成を抑制すると同時にLH の testosterone 合成促進作用も阻害するのが認められた. Cycloheximide $1 \mathrm{mg}$ を全身に投与しても同様 な成績が得られた. 更に Cycloheximide の投与は c-AMP の testosterone 合成促進作用も阻害するのが 認められた (Fig. 18). 以上の成績から LH の作用機序として Fig. 10 亿示された如く，c-AMP の合成を 促進し，ての c-AMP が核酸合成を介せず, turn over の速かな regulator protein の合成を介して testosterone 合成を促進するという機構の存在の可能性が示唆される. 然しながらこれら阻害物質を用いる実 験は，それが目的以外の種々の作用を有する可能性があり，従つて以上の成績はあくまで予備的なものであ り，今後の詳細な検討を必要とする.

\section{$\mathrm{VI}$ 結 語}

上上我々は LH の作用機序に関する研究成績を報告したが，要約すると次の通りである。

1）我々はラットおよびマウスにおいて辠丸の testosterone 合成分必を指標とする新しく，特異的な LH の生物検定法 (rat testicular vein blood testosterone method および mouse testicular testosterone method) を開発し，これを用いて in vivo における LH の作用機序を検討した.

2) LH の testosterone 合成促進効果は極めて速かで, ACTH の副胃に対するる作用と酷似して居り, 従つて LH の作用機序の研究に ACTH の作用機序の研究が極めて参考になるととが判明した.

3）LH の作用機序として Leidig 細胞における c-AMP の産成促進, c-AMP による turn over の速 かな作用蛋白の新生，それに引続く testosterone 合成の促進という仮説と両立しうる予備的実験成績が得 られた。

4 ）今後, との検定系を用いて LH の作用機序の in vivo における検討をつづけたいと考える.

終りに本 symposium 参加の機会を与えられた西川光夫会長, 座長の山村雄一, 宇井信生両教授に感謝す ると共に御指導, 御鞭達をいただいた東大中尾教授, 井林博士に哚謝致します, 又協同研究者の影山喜世子 
研究員補の労を多と致します.

\section{主要 文 献}

1) EIK-NES, K.B. : Endocrinology of the Testis. Golloquia on Endocrinology Vol. 16, P120, J. \& A. Churchill Ltd. London (1967).

2）大沢仲昭ほか：昭和44年 6 月内分泌学会東部部会例会発表.

3）大沢仲昭ほか：日本内分泌学会誌，45：516，(1969).

4) LIPSGOMB, H.S. and D.H. NELSON

: Endocrinology $71: 13$, (1962).

5）大沢仲昭ほか：第17回日本内分泌学会東部部会総会発表, (1969).

6) SUTHERLAND, E.W. et al. : Recent Progress in Hormone Research 21 : 623, (1965). 